\title{
Tinjauan Intermestik dalam Mekanisme Kebijakan Perubahan Iklim Global (REDD-UNFCCC): Persfektif Indonesia
}

\section{Apriwan}

Andalas Institute of International and Strategic Studies (ASISST), Program Studi llmu Hubungan Internasional, FISIP Universitas Andalas, Kampus Limau Manis, Padang, 25163

Email: apriwan@fisip.unand.ac.id

\begin{abstract}
The international regime of the United Nations Framework Convention on Climate Change (UNFCCC) has resulted some agreements and policies which binding its countries member. The latest one was the mechanism of REDD (Reducing Emissions From Deforestation and Forest Degradation). The implemetantion of these mechanism does not only bind and involve the countries member at the national level but also at local level (such as at province and regency level). Local aspect has a significant role as the basis for implementing these policy. This paper examines how instermestic perspective used for explaining the relation between international and domestic (local) aspect within the REDD-UNFCCC mechanism. Keywords: international regime, climate change, intermestic, Indonesia
\end{abstract}

\begin{abstract}
Abstrak
Rezim internasional Konvensi kerangka Kerja PPB tentang Perubahan Iklim (UNFCC) menghasilkan beberapa kesepakatan dan kebijakan yang mengikat untuk negara anggotanya. Mekanisme terbaru adalah ditetapkannya REDD (Pengurangan Emisi dari Deforestasi dan Degradasi Hutan). Pelaksanaan dari mekanisme ini tidak hanya mengikat dan melibatkan negara angota dalam tingkat nasional, namun juga melingkupi tingkat lokal (provinsi, kabupaten). Aspek lokal memiliki peran signifikan sebagai landasan dalam pelaksanaan kebijakan ini. Tulisan ini membahas bagaimana perspektif intermestik digunakan dalam menjelaskan hubungan antara aspek Internasional dan lokal dalam mekanisme REDD-UNFCC. Kata Kunci: rezim internasional, perubahan iklim, intermestik, Indonesia
\end{abstract}

\section{PENDAHULUAN}

Rangkaian panjang dari kerjasama internasional The United Nations Framework Convention on Climate Change (UNFCCC) telah menghasilkan agenda baru yang disebut dengan Reducing Emission from Deforestation and Degradation (REDD) yang dihasilkan melalui Conference of The Parties (COP) 13 di Bali pada 2007 lalu. Skema kebijakan ini merupakan langkah tindak lanjut dari kesepakatan yang tertuang pada Protokol Kyoto 1997, yang mana poin kesepakatan usaha pengurangan emisi gas karbon dengan target 5.2\% akan berakhir di 2012 ini (Soejachmoen dan Sari, 2003: 13). Dengan demikian diperlukan mekanisme lanjutan untuk penanggulangan prubahan iklim global yang dari hari ke hari menjadi perhatian semua pihak di berbagai level. REDD ini merupakan skema yang ditujukan bagi negara non-annex 1 countries, yaitu kelompok negara-negara berkembang yang memiliki hutan basah dengan tingkat produktifitas oksigen yang cukup signifikan bagi konsumsi oksigen dunia. 
Sebagai negara yang memiliki hutan cukup luas, Indonesia juga memiliki peluang untuk berkontribusi dalam penurunan produksi karbon dari sektor kehutanan. Melalui mekanisme REDD, Indonesia diharapkan bisa mewujudkan perekonomian rendah karbon dan sekaligus menunjukkan komitmen Indonesia dalam penanggulangan dampak perubahan iklim global, seperti yang digadang-gadangkan oleh Presiden Susilo Bambang Yudhoyono pada berbagai pertemuan internasional terkait perubahan iklim. Namun d isisi lain, ada pandangan yang pesimis, bahwa implementasi dari skema tersebut, justru akan merugikan masyarakat lokal dalam hak penggunaan pengelolaan hutan. Karena skema REDD ini akan bekerja dalam pengurangan aktifitas penggunanaan lahan, alih guna lahan, dan kehutanan (land-use, land-use change, and forestry/LULUCF) yang pada dasarnya terjadi di level daerah atau lokal (Yamni and Depledge, 2004: 184-190).

Berangkat dari kondisi tersebut, tulisan ini menggunakan cara pandang intermestik dalam menganalisa permasalahan kebijakan perubahan iklim global yang dihasilkan oleh rezim internasional perubahan iklim UNFCCC. Bagaimana kepentingan negara(nasional) memiliki sinergisitas dengan kepentingan domestik (daerah/lokal) dalam konteks isu dan kebijakan perubahan iklim global (internasional). Sehingga kebijakan global yang muncul juga merepresentasikan kebutuhan dan kepentingan dari aspek domestik (nasional dan lokal).

\section{METODOLOGI}

\section{UNFCCC SEBAGAI REZIM INTERNASIONAL PERUBAHAN} IKLIM

Berdasarkan laporan International Panel on Climate Change (IPCC), dampak perubahan iklim tidak hanya dalam konteks lingkungan semata, tetapi juga berkembang dalam aspek lainnya. Sosial, ekonomi dan lingkungan. Pemanasan global sebagai implikasi lain dari perubahan iklim merupakan dampak dari aktivitas modern yang kompleks, melibatkan dunia secara keseluruahan, kondisi ini juga berhubungan dengan kemiskinan, pertumbuhan ekonomi, ledakan penduduk. Dengan demikian, penanganannya tentu tidaklah mudah, dan mengabaikan isu ini juga berimplikasi sangat buruk atas keberlansungan kehidupan di muka bumi ini (http://unfccc.int/ essential_background/feeling_the_heat/items/2917.php).

Gareth Porter dan Janet Welsh Brown (1991), memetakan kemunculan lingkungan sebagai "isu global” sejak 1980-an. Kajian mereka menunjukkan bagaimana isu ini berkaitan dengan perkembangan interaksi baru diantara negara-negara untuk membentuk "rezim lingkungan global." Mereka juga menganalisa proses penetapan agenda lingkungan menciptakan hubungan baru antara isu lingkungan dengan keamanan internasional, relasi antara utaraselatan, maju-berkembang dan perdagangan dunia. Mereka menambahkan bahwa isu lingkungan telah menjadi agenda kebijakan global yang tidak terlelakkan (Porter and Brown, 2011: 240).

Dalam kondisi seperti ini dibutuhkan sebuah aturan baru untuk menampung dan mengatur berbagai isu dan aktivitas banyak aktor yang terus berkembang. Kebutuhan untuk menciptakan sebuah tatanan atau mekanisme global yang menjalankan fungsi yang ekuivalen dengan pemerintah negara bangsa menjadi sangat besar. Konsep International Regime menjadi gagasan untuk menjawab kebutuhan tersebut. Para ahli hubungan internasional melihat gagasan ini sebagai jawaban yang lebih efektif dalam menyelesaikan masalah-masalah global kekinian.

Menurut Krasner (1983), rezim internasional merupakan:

“...implicit or explicit principles, norms, rules, and decision-making procedures around which actors' expectations converge in a given area of international relations. Principles are beliefs of fact, causation, and rectitude. Norms are standards of behavior defined in terms of rights and obligations. Rules are specific prescriptions or proscriptions for action. Decision-making procedures are prevailing practices for making and implementing collective choice".

Dalam hal ini, Rezim internasional lebih menekankan pada norma internasional dalam mengontrol prilaku para aktor negara, norma dalam hal ini dimaknai sebagai bentuk hak dan kewajiban 
yang harus ditaati oleh aktor internasional terkait akan sebuah isu. Hak dan Kewajiban ini muncul melalui proses pengambilan keputusan oleh para aktor yang terlibat. Lebih lanjut, rezim internasional memberikan peluang bagi semua aktor untuk menyuarakan suara dan nilai yang mereka miliki.

Hansenclever dkk. (2007), menggunakan pendekatan kognitivisme untuk menjelaskan keberadaan rezim internasional. Menurut pendekatan ini, perilaku aktor tidak dibentuk sepenuhnya oleh kepentingan material, tetapi lebih pada peranan mereka dalam masyarakat. Dalam hal ini, kognitivis lebih menekankan pada hubungan intersubjektifitas dalam masyarakat internasional, dengan kata lain dunia kita ini adalah sebuah realita rekonstruksi sosial dimana orang-orang percaya akan apa yang mereka lakukan. Pendekatan ini lebih memandang negara sebagai aktor sosial yang tidak selalu sebagai aktor yang rasional. Sebagai aktor sosial, negara-negara bekerja dalam konteks struktur sosial mereka yang didasarkan pada aturan-aturan, norma-norma, identitas dan institusi (Caballero-Anthony, 2005: 32). Dengan demikian suatu negara tidak bertindak secara independen diluar struktur tersebut, tapi mengacu pada institusi itu sendiri, dengan kata lain struktur tersebut membantu menjelaskan perilaku negara-negara dan interaksinya dengan negara-negara lain.

Terkait dengan isu perubahan iklim global, melalui Earth Summit tahun 1992 di Rio de Jeneiro, Brazil dibuat suatu kerangka konvensi untuk perubahan iklim (United Nations Framework Convention on Climate Change-UNFCCC) yang ditandatangani oleh 162 negara. Kerangka konvensi ini ditujukan sebagai ikatan moral untuk mengurangi emisi gas karbondioksida di setiap negara-negara yang ikut menandatanganinya dengan mengatasi penyebabnya (mitigasi) dan mengantisipasi akibatnya (adaptasi) (Farhana and Depledge, 2004: 184-190).

UNFCCC sebagai bentuk rezim perubahan iklim memiliki andil yang cukup signifikan dalam merumuskan dan mengangkat isu-isu perubahan iklim dan pemanasan global menjadi isu dan norma internasional. Dalam konteks ini, UNFCCC muncul dari proses intersubjektif antar aktor negara, yang menyadari bahawa permasalahan perubahan iklim adalah permasalahan global, dimana tidak bisa diselesaikan begitu saja oleh satu atau dua negara saja. Akan tetapi menjadi tanggungjawab secara menyeluruh, baik oleh aktor-aktor negara maupun non negara. Dan yang lebih penting, isu perubahan iklim dan pemanasan global merupakan isu yang diangkat atas dasar kepentingan keberlangsungan umat manusia di masa sekarang dan masa yang akan datang, sebagai akibat dari kerusakan lingkungan yang diakibatkan oleh manusia juga.

Sebagai bentuk proses intersubjektifitas, UNFCCC dalam kerangka kerjanya tentu harus mempertimbangkan berbagai aspek pada berbagai level. Artinya, kebijakan-kebijakan yang dihasilkan harus mampu mengakomodir semua pihak dengan tetap mengutamakan kepentingan lingkungan itu sendiri. Misalkan, kesepakatan yang tertuang dalam Skema Protokol Kyoto pada tahun 1997, yang mewajibkan seluruh Negara Annex I (negara-negara maju) untuk secara bersama-sama menurunkan emisi gas rumah kaca rata-rata sebesar 5,2\% dari tingkat emisi tahun 1990 pada periode tahun 20082012(Soejachmoen, Moekti H dan Sari, 2003: 13). Protokol ini memiliki tiga mekanisme yang fleksible, yaitu Join Implementation (JI), Carbon Trading (CT), dan Clean Development Mechanism (CDM). Disisi lain, REDD sebagai bentuk pelibatan lebih lanjut atas partisipasi negara-negara berkembang atau negara non annex 1 , harusnya juga memberikan peluang dan fleksibelitas yang bisa mengkover berbagai kepentingan baik pada tataran global maupun domestik dalam konteks kepentingan lokal/daerah.

\section{PEMBAHASAN}

PENDEKATAN INTERMESTIK PADA KEBIJAKAN REZIM PERUBAHAN IKLIM GLOBAL REDD-UNFCCC

Konsep intermestik muncul seiring dengan meningkatnya fenomena globalisasi. Batas-batas tradisional negara bangsa(nasional) semakin kabur dengan dunia internasional. Keterkaitan antara struktur domestik dan struktur internasional semakin 
kental, seiring perkembangan teknologi komunikasi dan informasi, meningkatnya arus barang dan manusia dari dan ke berbagai negara dan belahan dunia. Fenomena ini muncul dalam berbagai diskusi publik dan kajian akademis. Kajian tentang hubungan antar domestik dengan hubungan internasional cukup banyak dan bervariasi. Rosenau misalnya memulai dengan konsep "linkage politics" yang melihat hubungan antar level (domestik dan internasional) ini sebagai pola prilaku konflik (conflict behavior). Lebih lanjut Katzeinsten dan Krasner melihat determinasi domestik dalam kebijakan luar negeri suatu negara melalui faktor struktural, terutama dalam kontek kebijakan ekonomi luar negeri. Menurut mereka, tujuan utama dari segala strategi kebijakan ekonomi suatu negara adalah untuk menjadikan kebijakan domestik kompatibel dengan ekonomi politik internasional (Putnam, 1988: 427. 460). Apa yang akan diperjuangkan dalam level internasional, suatu negara harus memperimbangkan dan memperhatikan apa yang menjadi kebutuhan dan kepentingan pada level domestik.

Lebih lanjut, Putnam (1988), menawarkan sebuah kerangka atau model yang reliable untuk menjembatani faktor domestik dan internasional atau faktor internal dan eksternal dengan pendekatan "two level games," konsep ini menjelaskan bagaimana faktor domestik suatu negara sangat menentukan keberhasilan politik luar negeri mereka di tengah konstelasi politik internasional. Untuk itu diperlukan sinergisitas antara kedua level tersebut, sehingga bisa memudahkan dan menguatkan proses perumusan kebijakan maupun implementasi dari kebijakan luar negeri (Starr, 2006: 4).

a. Level pertama, berada pada konteks terjadinya proses diplomasi atau negosiasi yang dilakukan dalam level internasional, seorang diplomat akan berhadapan dengan diplomat lainnya dalam memperjuangkan politik luar negeri mereka masingmasing.

b. Level Kedua, diasumsikan sebagai proses negosiasi dan diplomasi yang dilakukan dalam konteks domestik, apakah itu dengan parlemen, LSM, Daerah, dan berbagai sektor domestik lainnya, yang memiliki pengaruh dan terkait dengan isu kebijakan luar negeri suatu negara bangsa.

Berangkat dari paparan di atas, Putnam secara eksplisit mengkaitkan antara "win-set" politik domestik akan menentukan suksesnya aktifitas diplomasi dan penandatanganan dari sebuah kesepakatan internasional. Win-set dalam hal ini mengacu kepada proses kesepakatan pada level kedua (domestik) yang akan memberikan justifikasi dan legtimasi bagi level pertama untuk memperjuangkan politik luar negerinya. Semakin kuat kesepakatana pada level kedua maka semakin besar kemenangan (win) yang diperoleh pada level pertama. Dan begitupun sebalikny, apa yang dicapai pada level pertama akan menjadi mudah untuk diterima dan diimplementasikan pada level kedua. Sederhananya, diplomasi politik luar negeri suatu negara tidak semata merepresentasikan dan memproyeksikan kepentingan nasional mereka, akan tetapi bagaimana proses diplomasi juga menempatkan faktor domestik sebagai tolak ukur bagi keberhasilan politik luar negerinya, dengan demikian dibutuhkan kemampuan untuk mengkomunikasikan dan mensinergiskan perkembangan-perkembangan yang terjadi dalam dunia internasional/global ke dalam negeri (domestik).

Dalam konteks rezim perubahan iklim global (UNFCCC), ketetapan yang dihasilkan semestinya memang mencerminkan kesepakatan-kesepakatan di tingkat domestik, perlu adanya proses pemahaman pada struktur, kepentingan dan kebutuhan domestik terkait isu perubahan iklim tersebut. Artinya diplomasi pada level pertama, benar-benar mencerminkan kebutuhan dan kepentingan domestik (mulai dari level nasional/pusat sampai pada level daerah/lokal), sehingga output kebijakan yang diperoleh pada level pertama tersebut memiliki sinergisitas disaat di implementasikan di level kedua (domestik) tersebut.

Permasalahan yang muncul saat ini, output Kebijakan Perubahan Iklim seperti Skema Protokol Kyoto ataupun REDD menjadi tidak populis di level domestik, dalam hal ini adalah konteks daeral/lokal. Hal ini dikarenakan proses "win sets" ini memang 
belum sepenuhnya dilakukan pada level lokal. Sementara implementasi dan pelaksanaan kebijakan perubahan iklim tersebut akan lebih banyak bekerja pada level daerah/lokal. Sehingga efektifitas kebijakan menjadi tidak tepat sasaran, dan pada akhirnya juga akan memberikan dampak pada reputasi suatu negara di dunia internasional.

\section{REDD-UNFCCC DI INDONESIA; REPRESENTASI KEPENTINGAN NASIONAL DAN DAERAH?}

Komitmen Indonesia dalam menanggulangi isu perubahan iklim global ditandai dengan meratifikasi keanggotaannya dalam UNFCCC melalui Undang Undang No. 6 Tahun 1994 dan juga telah meratifikasi skema kebijakan dalam Protokol Kyoto melalui UU no. 17/2004 (Apriwan, 2010). Keberlanjutan dari Skema Protokol Kyoto di atas akan diperbaharui pada 2012, dan Skema pengurangan emisi dan deforestasi dan degradasi hutan (REDD) dipromosikan sebagai salah satu skema yang akan dijadikan penerus skema pengurangan emisi gas rumah kaca bagi negara-negara berkembang. Skema ini bertujuan untuk "memberi harga” pada karbon yang bisa diserap hutan dan yang bisa ditahan jika terjadi penebangan hutan.

Sederhananya skema REDD memberikan insentif kepada negara-negara pemilik hutan tropis untuk menjaga dan tidak mengekploitasi hutannya untuk kepentingan ekonomi (Ica, 2010: 55).

Kondisi ini memungkinkan bagi pihak negara maju untuk membeli karbon ke negara-negara berkembang melalui produksi hutan mereka, pembelian karbon ini diasumsikan sebagai bentuk kompensasi negara-negara maju untuk menurunkan produkis emisi $\mathrm{CO} 2$ mereka yang melebihi standar yang telah ditetapkan oleh UNFCCC. Sederhananya, dengan membayar Oksigen yang dihasilkan oleh hutan negara-negara berkembang, negara-negara maju tidak harus menurunkan produksi emisi karbon, tetapi bisa diganti dengan mekanisme perdagangan karbon melalui skema REDD tersebut.

Indonesia sebagai negara berkembang cukup proaktif untuk berpartisipasi dalam skema terakhir ini. Dengan luas hutan sekitar 144 juta hektar dan merupakan negara yang memiliki hutan tropis terluas ketiga di dunia, Indonesia merupakan pasar yang potensial dalam penerapan skema REDD tersebut. Partisipasi Indonesia ini terlihat dari aktifnya Indonesia mempromosikan skema REDD ini disetiap pertemuan UNFCCC mulai dari COP 13 Bali 2007 sampai pada COP 15 Copenhagen 2009. Komitmen Indonesia ini juga tercermin dari pernyataan Presiden Susilo Bambang Yudhoyono pada COP 15, bahwa Indonesia optimis untuk menurunkan GHG Emission nya dari $26 \%$ (berdasarkan skenario Business As Usual$B A U)$ menjadi $41 \%$ dengan bantuan negara-negara industry maju pada tahun 2040 (Purwanto, Sartika dan Rahman, 2010: 2).

Meskipun di level pemerintahan nasional Indonesia terkesan optimis dalam menerapkan skema REDD ini, akan tetapi masih banyak pro dan kontra terkait kesiapan di tingkat lokal maupun nasional. Dimana, adanya keprihatinan bahwa skema REDD hanya memprioritaskan kepentingan konservasi dan menguatkan kontrol negara/global terhadap pemanfaatan pengelolaan hutan. Sementara isu pengentasan kemiskinan, bagi masyarakat yang hidupnya bergantung pada hutan,termasuk masyarakat adat, justeru tidak mendapatkan porsi yang seimbang. Belum lagi adanya, ketimpangan atau tarik menarik antara kepentingan pemerintah pusat dan daerah dalam membagi hasil program dari skema REDD. Sehingga muncul keprihatinan lebih dalam mengingat bahwa skema REDD yang didanai oleh institusi yang dikontrol oleh negara maju (seperti Bank Dunia), atau sektor swasta (melalui pasar karbon) hanya akan melayani kepentingan negara-negara dan perusahaan itu, daripada penduduk yang tinggal dan bergantung pada hutan demi keberlansungan kehidupan mereka (Keadilan Iklim dan Penghidupan yang Berkelanjutan, 2008).

Kondisi ini disebabkan program-program yang akan diturunkan melalui skema REDD tersebut, secara nyata akan lebih banyak bekerja pada level lokal, artinya pihak daerah atau masyarakat seputar hutan merupakan bagian penting yang tidak bisa terpisahkan dalam implementasi skema kebijakan perubahan iklim global tersebut. Namun respon daerah maupun 
nasional terkait skema tersebut masih cukup rendah. Respon dalam hal ini terkait akan inisiasi, adaptasi dan antisipasi dari daerah melalui kesiapan masyarakat dan pemerintah, serta kesiapan kelembagaan dan kebijakan baik di tingkat nasional maupun daerah.

Dalam konteks ini, hasil riset Purwanto, dkk, (2010) dari CIFOR menjadi ulasan yang menarik. Mereka menemukan bahwa adanya aspek sosial budaya terkait pada pemanfaatan sumber daya alam seperti hutan. Kondisi ini berangkat dari keberadaan komunitas lokal disekitar wilayah sumber daya. Komunitas lokal yang pada umumnya hidup dalam alam sub-sistem atau pra-kapitalis selama ini menjadi tersisihkan karena kehadiran pemerintah dan swasta melalui investasi modal pertambangan dan perusahan konsesi hutan di sekitar kawasan sumber daya. Polapola ini selalu muncul pada program-program pembangunan yang menempatkan komunitas lokal termarginalkan ketika berhadapan dengan ekonomi kapitalis.

Kondisi ini akan semakin kompleks dengan kehadiran kebijakan perubahan iklim global seperti REDD yang hadir sebagai kebijakan dan isu baru yang dilandaskan pada pemahaman saintifik atas fenomena ekologi dunia saat ini (World Values). Rangkaian riset yang mereka lakukan di pedalaman Kalimantan, menunjukkan bagaimana komunitas lokal yang awalnya hidup dengan teknologi sederhana dan sistem ekonomi pra kapital di pedalaman Kalimantan mencoba bertahan di tengah maraknya penenaman modal dan isu global seperti kebijakan perubahan iklim global UNFCCC melalui skema kebijakan REDD yang diterapkan disana. Ada beberapa poin yang dirumuskan dari penelitian ini, antara lain pertama, bahwa kebijakan pemerintah terkait dengan mitigasi perubahan iklim tidak berpengaruh secara signifikan terhadap kehidupan ekonomi sosial dan budaya masyarakat lokal. Hal ini terlihat dari eksploitasi SDA yang terus menerus terjadi. Kedua, adanya traumatik masyarakat lokal atas kebijakan konservasi yang melarang mereka untuk mengakses hutan yang dianggap secara kultural sebagai bagian dari diri mereka. Ketiga, perlunya pelibatan kelembagaan lokal/adat dalam proses perumusan kebijakan pengelolaan hutan di kawasan. Dan yang terakhir, kurang memadainya pemahaman masyarakat terhadap dampak perubahan iklim, menjadikan kerja sosialisasi harus lebih komprehensif dan menjangkau kelompok komunitas secara nyata (Purwanto, 2010: 3).

Lebih lanjut, Wulansari (2010) memberikan pandangan bahwa adanya potensi konflik dalam penerapan skema REDD di Indonesia. REDD dinilai berpotensi mengabaikan, bahkan melanggar hak-hak masyarakat adat atas hutan yang telah menjadi sumber penghidupan mereka sejak lama. Masyarakat lokal Sumatera dan Papua memiliki kepercayaan bahwa hutan termasuk dalam kehidupannya, sementara pemerintah lokal, provinsi maupun nasional berhak menyewakan lahannya kepada perusahaan. Sehingga mekanisme REDD hanyalah melibatkan pemerintah atau kepentingan yang terkait semata, tanpa mengakomodir kepentingan masyarakatnyang bermukin di sekitar hutan (Ica, 2010: 55).

Kemudian, untuk konteks Sumatera Barat misalnya, dengan luas hutan 4.228.730,00 Hektar (http://www.dephut.go.id/files/ Sumbar_07_Luas_Kws_Hutan.pdf) yang tersebar di 19 kabupaten/kota merupakan daerah yang cukup signifikan terkait skema kebijakan REDD tersebut. Seperti yang dilaporkan harian Padang Ekspres, beberapa negara seperti Australia dan Singapura ingin menjalin perdagangan karbon dengan Sumatera Barat, akan tetapi karena belum ada regulasi yang jelas tentang mekanisme penjualan karbon tersebut, Pemerintah Sumatera Barat selalu menunda kerjasama tersebut (Perdagangan Karbon Ditunda, Padang Ekspress, 20/04/2011). Kondisi ini sangat jelas menunjukkan bahwa kesiapan pemerintahan daerah masih rendah. Belum lagi pada level masayarakat. Di samping itu, masalah kepemilikan lahan di Sumatera Barat termasuk cukup kompleks, hal ini terkait dengan hukum adat yang mengakui hak-hak masyarakat adat/ nagari terhadap tanah ulayat yang ada di suatu nagari.

Seperti yang diungkapkan Afrizal (2007), bahwa komunitas nagari cukup aktif melawan negara dan bisnis terkait kepemilikan lahan sawit yang dimiliki 
HPH yang diakui oleh negara. Konflik ini tersebar di nagari-nagari di berbagai kabupaten di Sumatera Barat. Perlawanan yang muncul semenjak reformasi bergulir di tahun 1998 ini, sampai saat ini masih banyak yang belum terselesaikan. Dengan demikian, skema REDD yang akan berkaitan dengan pemanfaatan lahan hutan di Sumatera Barat, secara tidak lansung akan berhadapan dengan kepemilikan tanah ulayat yang juga merupakan hutan yang akan menjadi komoditas perdagangan karbon dalam skema kebijakan perubahan iklim global REDD. Artinya, konflik atas penggunaan lahan akan semakin kompleks, seiring munculnya keberadaan REDD yang mau tidak mau akan dialami oleh setiap daerah di Indonesia.

Jika strategi nasional REDD Indonesia tidak mengakomodir kepentingan dan konteks lokalitas seperti yang ada di Sumatera, Kalimantan dan Papua ini, bisa diperkirakan masalah baru akan muncul kembali dalam sektor penggunaan lahan hutan di wilayah ini. Draf strategi REDD Indonesia yang sedang disusun, benar-benar harus mempertimbangkan keadaan/kondisi di wilayah-wilayah tertentu. Sehingga kebijakan perubahan iklim global tidak bersifat parsial (nasional) semata, akan tetapi merupakan produk kebijakan yang utuh mewakili kepentingan domestik pada berbagai sektor dan level.

Sederhananya, ada beberapa faktor yang harus menjadi perhatian pemerintah pusat dalam merumuskan dan mengimplementasikan REDDUNFCCC dengan menggunakan pendekatan intermestik ini, pertama, Pemerintah harus bisa mengakomodir dan mensinergiskan kebutuhan domestik baik pada level nasional maupun pada level lokal. Sehingga tidak terkesan satu pihak merasa terabaikan, sementara pihak lain mendapatkan porsi yang ideal, seperti yang terjadi pada kasus REDD di Kalimantan. Hal ini bisa dilakukan dengan serangkaian assessement dan sosialisasi yang melibatkan berbagai pihak seperti akademisi dan NGOs. Kedua, adanya pelibatan dari berbagai stakeholders secara pastisipatif dalam merumuskan berbagai kebutuhan dan kebijakan terkait implementasi skema REDD tersebut. Ketiga, mempersiapkan instrumen berupa regulasi dan institusi pada level pusat dan daerah. Keempat, kesemua tahapan tersebut harus menjadi acuan dan pedoman yang dibawa oleh wakil Indonesia dalam setiap proses negosiasi implementasi REDD di tingkat Internasional. Dengan demikian, kekeliruan koordinasi dalam

\section{KESIMPULAN}

Berangkat dari paparan di atas, dipahami bahwa produk kebijakan perubahan iklim global UNFCCC, khususnya terkait dengan skema REDD perlu memang mempertimbangkan kembali konteks domestik (daerah), dalam artian bagaimana kondisi nyata, kebutuhan dan kepentingan domestik tersebut terakomodir dalam skema kebijakan yang dihasilkan. Model two level games yang ditawarkan oleh Putnam cukup reliable memberikan gambaran bagaimana hubungan domestik dan internasional (intermestik) harusnya dibangun dalam proses diplomasi dan negosiasi dalam level rezim perubahan iklim global.

Pendekatan ini memberikan pemahaman bahwa, proses diplomasi tidak semata hanya berbicara dalam konteks kepentingan nasional, akan tetapi lebih luas melihat bagaimana proses diplomasi juga merefleksikan kemampuan mengkomunikasikan kondisi global ke dalam konteks domestik, dan begitu juga sebalikanya memperjuangkan kepentingan dan kebutuhan domestik dalam ranah rezim internasional perubahan iklim. Dengan demikian, sinergisitas antara faktor domestik (lokal) dengan kondisi global/ internasional bisa tercermin dalam kebijakan-kebijakan yang dihasilkan (win-set). Lebih lanjut, implementasi kebijakan perubahan iklim global pada level domestik akan lebih acceptable dan populis karena kebijakan yang dirumuskan tidak lagi bersifat parsial melainkan bersifat menyeluruh (komprehensif) yang merefleksikan kebutuahan dari berbagai sektor dan level.

\section{BIBLIOGRAFI}

Afrizal. 2007. The Nagari Community, Business and the State: the Origin and the Process of Contemporary Agrarian Protest in West Sumatera, Indonesia. Bogor: Sawit Watch and Forest People Prorame.

Apriwan. 2010. Clean and Development Mechanism in Indonesia. 
Makalah dipresentasikan pada Environmental Policy Program. International University of Japan, Japan Maret.

Hasenclever, Andreas, Peter Mayer and Volker Rittberger. 1997

Theories of International Regimes. Cambridge: Cambridge University Press.

Ica, Wulansari. 2010. Deforestasi di Indonesia dan Mekanisme REDD. Jurnal IImiah Hubungan Internasional, Volume 6 No.2 PACIS Universitas Katolik Parahyangan, Bandung.

Jack M, Hollander. 2003. The real environmental crisis: why poverty, not affluence, is the environment's number one enemy. Berkeley: University of California Press.

Keadilan IKlim dan Penghidupan yang Berkelanjutan, Kompilasi News Letter Down To Earth (DTE), 2008, KIPPY Print Solution.

Lester, James P. and Joseph Stewart. 2000. Public Policy and Evolutionary Approach. Second edition. Australia: Warsworth.

Luas Kawasan Hutan Sumatera Barat. (Online), (http:// www.dephut.go.id/files/Sumbar_07_Luas_Kws_Hutan.pdf, diakses 12 Juli 2011).

Noordwijk, Meine van, Herry Purnomo, Leo Peskett and Bambang Setiono. 2008. Reducing emissions from deforestation and forest degradation (REDD) in Indonesia: options and challenges for fair and efficient payment distribution mechanisms. Working paper 81, World Agroforestry Centre (ICRAF), Bogor, Indonesia.

Padang Ekspres. 20 April 2011. Perdagangan Karbon Ditunda. (Online), (http://unfccc.int/essential_background/feeling_the_heat/items/ 2917. php, diakses 10 Juni 2009).

Purwanto, Semiarto Aji, Iwi Sartika, Rano Rahman. 2010. Kesiapan dan kerentanan sosial dalamskema kebijakan perubahan iklim/REDD di Indonesia. Kertas Kerja Epistema No.08/2010, Jakarta: Epistema Institute.

Republik Indonesia. 1994. Undang-Undang Republik Indonesia No. 06 Tahun 1994, Departemen Dalam Negeri Republik Indonesia. Jakarta.

Republik Indonesia. 2004. Undang-Undang Republik Indonesia no 17 Tahun 2004. Departemen Dalam Negeri Republik Indonesia. Jakarta.

Republik Indonesia. 2005. Undang-Undang Republik Indonesia Nomor 22 Tahun 1999 tentang Pemerintah Daerah, Departemen Komunikasi dan Informatika. Jakarta.

Soejachmoen, Moekti H dan Omar Sari (ed). 2003. Mencari Pohon Uang: CDM Kehutanan di Indonesia. Jakarta: Pelangi.

Wiharani, Annisa Paramita. 2011. Copenhagen Accord: Sebuah Kemajuan Kompromi Politik Hukum Internasional Perubahan Iklim Multiversa Journal of International Studies, Volueme 02 (1).

Winnefeld, James A. and Marry, E Morris. 1994. Where Environmental Concerns and Security Strategies Meet; Green Conflict in Asia and Middle East. Rand, St. Monica.

Yamin, Farhana and Joanna Depledge. 2004. The International Climate Change Regime A Guide to Rules, Institutions and Procedures. Cambridge: Cambridge University Press. 